\title{
Is the biochar produced from sewage sludge a good quality solid fuel?
}

\author{
Jakub Pulka1 ${ }^{1}$ Dariusz Wiśniewski², Janusz Gołaszewski ${ }^{3}$, Andrzej Białowiec $^{1 *}$ \\ ${ }^{1}$ Wrocław University of Environmental and Life Sciences, Poland \\ Institute of Agricultural Engineering \\ Faculty of Life Sciences and Technology \\ ${ }^{2}$ University of Warmia and Mazury, Poland \\ The Faculty of Technical Sciences \\ ${ }^{3}$ University of Warmia and Mazury, Poland \\ Research Center for Renewable Energy \\ *Corresponding author’s e-mail: andrzej.bialowiec@up.wroc.pl
}

Keywords: torrefaction, sewage sludge, biochar, calorific value, solid fuel, ash.

\begin{abstract}
The influence of sewage sludge torrefaction temperature on fuel properties was investigated. Non-lignocellulosic waste thermal treatment experiment was conducted within $1 \mathrm{~h}$ residence time, under the following temperatures: 200, 220, 240, 260, 280 and $300^{\circ} \mathrm{C}$. Sawdust was used as lignocellulosic reference material. The following parameters of biochar have been measured: moisture, higher heating value, ash content, volatile compounds and sulfur content. Sawdust biochar has been confirmed to be a good quality solid fuel. High ash and sulfur content may be an obstacle for biochar energy reuse. The best temperature profile for sawdust torrefaction and fuel production for $1 \mathrm{~h}$ residence time was $220^{\circ} \mathrm{C}$. At this temperature the product contained $84 \%$ of initial energy while decreased the mass by $25 \%$. The best temperature profile for sewage sludge was $240^{\circ} \mathrm{C}$. The energy residue was $91 \%$ and the mass residue was $85 \%$. Higher temperatures in both cases caused excessive mass and energy losses.
\end{abstract}

\section{Introduction}

Large quantities and organic character of sewage sludge cause that it has great potential for renewable energy production and may be a source of good quality solid fuel - biochar, when the torrefaction process is applied.

Biochar is a carbon rich product obtained by thermal decomposition of biomass in torrefaction process (Mimmoa et al. 2014). During the process, the biomass partly decomposes giving off various condensable and non-condensable gases. The final product is a carbon rich solid, which is referred to as torrefied biomass, biochar, biocarbon (Lehmann et al. 2011). In the literature, the torrefaction process is also referred to as roasting, slow and mild pyrolysis, wood-cooking and high-temperature drying (Bergman 2005).

The principal characteristics of torrefied products are as follows:

High Energy Density: Torrefied biomass contains $70-80 \%$ of the original weight while retaining $80-90 \%$ of original biomass energy. As a result, its energy density can increase by around 30\% (Ciolkosz and Wallace 2011).

Hydrophobicity: Torrefied biomass becomes hydrophobic, i.e., it does not absorb moisture or its equilibrium moisture percentage drops to very low values from 1 to $3 \%$ (Lipinsky et al. 2002).
Increased Fixed Carbon: The fixed carbon content of torrefied biomass is high. For example, depending on the treatment temperature and duration, it is between $25 \%$ and $40 \%$, while the ash content is low. This property makes the torrefied material a very attractive reducing agent (Bergman 2005).

Reduced Oxygen: Torrefaction reduces the $\mathrm{O} / \mathrm{C}$ ratio through reduction in oxygen. This makes the biomass better suited for gasification due to its lower O/C ratio (Prins 2005). In addition to its higher heating value, torrefied biomass also produces less smoke when it burns. This is because the smoke-causing volatiles are already driven off during the torrefaction process and the biomass is also dry.

Improved Grindability: Torrefied biomass grindability is superior to that of raw biomass. The output of a pulverizing mill can increase by 3-10 times (Bridgeman et al. 2010, Phanphanich and Mani 2011).

Combustion Properties: Torrefied biomass takes less time for ignition due to lower moisture and it burns longer due to larger percentage of fixed carbon compared to raw biomass (Bridgeman et al. 2008).

Temperature and retention time are two main parameters that influence torrefaction process efficiency (Wannapeera and Worasuwannarak 2012). Torrefaction is usually conducted at temperatures between $200-300^{\circ} \mathrm{C}$ (Eseltine et al. 2013), and 
the designated temperature is maintained for 15 to $60 \mathrm{~min}$ (Verhoeff et al. 2011). Choosing specific value of those two key parameters for different types of biomass is essential for cost effective biomass treatment.

Torrefaction is a biomass treatment method for future utilization in co-firing in gasification process (van der Stelt et al. 2011). The process is commonly applied for lignocelluloses biomass treatment (Ratte et al. 2011). Lignocelluloses are built of 3 polymers: hemicelluloses, lignin and cellulose. Hemicelluloses are the most reactive forms of those three polymers and their carbonization and devolatization occur at temperatures below $250^{\circ} \mathrm{C}$ (Bergman and Kiel 2005). Vegetable biomass is used most commonly as the stock in torrefaction process. This biomass can be divided into two groups: green waste and energetic forestry products. Plants with the highest lignocelluloses percentage compared to sugars and fats have best energetic potential (Montross and Crofcheck 2010). Feedstocks currently used in commercial scale or in research facilities include wood chips and wood pellets, tree bark, crop residues (straw, nut shells and rice hulls), switch grass, organic wastes including distillers' grain, bagasse from the sugarcane industry, olive mill waste, chicken litter, dairy cattle manure, and paper sludge (Sohi et al. 2009).

Furthermore, all the considered biomass types are not just lignocellulosic by nature. Some waste biomass types, such as sewage sludge (Dhungana 2012), digestate from biogas plants (Wiśniewski and Gołaszewski 2013) and agricultural animal waste (Wiśniewski and Gołaszewski 2013) consist of fats, proteins and other organic matter, with very low lignocellulose content. Due to wide-scale urbanization, production of such wastes has increased substantially and the torrefaction process may help utilize this large volume of non-lignocellulosic biomass. The current absence of direct research in this particular area renders torrefaction decidedly under-utilized.

European Union countries produced almost 11 million tons of dried sewage sludge in 2005 and it is estimated that due to new European Union directive for EU-12 that number will reach 13 million in 2020. Sewage sludge production differs significantly between different countries in Europe. Germany, UK, Spain, France and Italy are the biggest producers in EU-15 countries. The sum of these countries production adds up to $73 \%$ of total productions in EU-15. Poland was the single greatest sewage sludge producer in EU-12 countries, producing almost $0.5 \mathrm{M}$ tons, it was almost $42 \%$ of total sludge amounts. The comparison of specific sludge production (expressed as kg per p.e. and year) shows the highest specific sludge production for all EU-27 countries in Austria, followed by UK, Finland and Luxembourg. Significant differences are observed between different countries as well as between old and new Member States, resulting in mean specific sewage sludge production equal to 21.9 and $11.5 \mathrm{~kg}$ per p.e. and year for EU-15 and EU-12, respectively. These differences are due to variations in percentages of population that are served by centralized wastewater treatment systems (WWTSs) as well as to variations in wastewater treatment applied in each country and contribution of the industrial sector (Kelessidis and Stasinakis 2012).

Several Directives have influence on sludge management but the most significant are the Directives: 2000/60/EC on water protection (Water Framework Directive), 91/271/
EEC on urban waste water treatment, 99/31/EC on the landfill of waste, and $86 / 278 / \mathrm{EEC}$ on the use of sludge in agriculture. In particular, the Water Framework Directive $(2000 / 60 /$ EC) targets the long-term progressive reduction of contaminant discharges to the aquatic environment in urban wastewater, while the Council Directive 91/271/EEC adopted in 1991, concerns urban waste water treatment and aims at the protection of the water environment from the adverse effects of discharges of urban waste water and from certain industrial discharges. It led to $50 \%$ increase in sludge production by year 2005, i.e. 10 million tons annually (Werle 2012).

The work of the European Commission (since 2000) is influencing the tightening of agricultural use of sewage sludge. This is due to the results of numerous and detailed studies of sewage sludge from different EU countries indicating a potential threat to soils caused by not only heavy metals but also organic pollutants contained in sewage sludge. Therefore the role of thermal treatment is increasing (Bień and Nowak 2014).

The proportion of land waste reuse has also changed dramatically in recent years. While in some Member States, such as France, Portugal, Spain and the UK, quantities reused in agriculture have continued to increase, agricultural application has effectively been banned in some countries, e.g. the Netherlands and some regions of Belgium (Flanders) (Kelessidis and Stasinakis 2012).

Incineration and landfilling are the main alternative methods of agricultural reuse for sludge management. In recent years, the thermal treatment of SS has become more popular (Stasta et al. 2006). Most Member States treat a portion of their sludge by incineration and the residual ash is usually disposed of to landfills. The quantity of sludge that is incinerated increases significantly when recycling is discouraged or banned. In Flanders (Belgium) for instance, more than $70 \%$ of sludge production is incinerated now. In the Netherlands, about $60 \%$ of sewage sludge is incinerated while in Austria, Denmark and Germany that percentage is approximately $40 \%$. Slovenia dries and then sends $50 \%$ of its SS out of the country to be incinerated (Smith 2008). There is a large variety of thermal SS processes, ranging from simple combustion, through wet oxidation, pyrolysis to gasification.

Unfortunately, the high water content of the SS reduces somewhat its value for reuse as large volumes have to be stored, transported and burned. Finally, the SS is considered to be hardly manageable waste, although it can also be perceived as valuable material whose potential for further conversion into solid fuel has not been revealed yet.

Several procedures have been implemented to reduce SS water content, mostly involving SS drying by applying belt dryers, drum dryers, solar dryers (greenhouses), evaporators or thermal dryers. The SS drying overcomes logistical and environmental problems appearing when conventional techniques of SS management are used. Additionally, SS drying brings several new approaches to SS utilization for energy production, such as the second generation solid fuel - biochar production, which are under investigation. Among numerous examples of such studies, novel approaches are distinguishable, such as SS use to produce biochar through torrefaction process (Dhungana 2012).

We believe that converting SS to biochar increases fuel prosperities of the product significantly and hence, it can 
be used as an energy source. Considering the temperature as a main factor influencing the torrefaction process we present the experiment, the aim of which was to investigate the influence of torrefaction temperature on chemical composition and energetic value of biochar derived from sewage sludge.

\section{Materials and method}

\section{Material characteristic}

Two types of biomass/waste: non-lignocellulosic - sewage sludge (SS) and lignocellulosic - oak sawdust (reference material) were used in the experiment.

The sewage sludge came from municipal wastewater treatment plant in Olsztyn, Poland, where it was anaerobically digested and centrifuged. Oak sawdust was provided by sawmill in Uniszewo, Poland. Average values of parameters characterizing these materials are shown in Table 1.

\section{The experiment configuration and control}

Both materials where thermally processed at the following temperatures: $200,220,240,260,280$ and $300^{\circ} \mathrm{C}$. This temperature range is consistent with classical torrefaction temperature range (Dhungana 2012) . One hour torrefaction time was chosen due to high sewage sludge moisture, according to (Dhungana 2012). Every experimental variant was carried out in 6 repetitions.

The tests on the biochar production process were conducted in a bath reactor (Fig. 1), which was a CEM Phoenix microwave furnace, where particular feedstock was thermally treated. The reactor was equipped with a process temperature control system.

SS was fed into the reactor in $100 \mathrm{ml}$ porcelain crucibles. At the beginning of every measurement, the crucible was weighted and filled with material to $75 \%$ of its crucible volume, then the crucible was weighed with $0.1 \mathrm{mg}$ accuracy and transferred to the furnace. Heating up always started at

Table 1. Average values of untreated materials' parameters (analyzed samples number $\mathrm{N}=6$ )

\begin{tabular}{|c|c|c|}
\hline & \multicolumn{2}{|c|}{ Material type } \\
\hline Parameter & sawdust & sludge \\
\hline Moisture [\%] & $55.8 \pm 1.16$ & $82.6 \pm 0.53$ \\
\hline Higher heating value [MJ/kg d.b.] & $19.3 \pm 0.12$ & $14.7 \pm 0.22$ \\
\hline Higher heating value [daf] [MJ/kg d.b.] & $19,41 \pm 0.13$ & $22.24 \pm 0,4$ \\
\hline Lover heating value [MJ/kg d.b.] & $7.1 \pm 0.25$ & $0.5 \pm 0.11$ \\
\hline Lover heating value [daf] [MJ/kg d.b.] & $16.3 \pm 0,17$ & $4.62 \pm 0,74$ \\
\hline Volatile compounds [\%] & $77,6 \pm 0,25$ & $54.4 \pm 4.9$ \\
\hline Ash [\%] & $0.5 \pm 0.12$ & $34 \pm 0.64$ \\
\hline $\mathrm{C}[\%]$ & $50.8 \pm 0.78$ & $32.9 \pm 0.53$ \\
\hline $\mathrm{H}[\%]$ & $5.6 \pm 0.18$ & $4.3 \pm 0.06$ \\
\hline $\mathrm{S}[\%]$ & $0.01 \pm 0.003$ & $1.5 \pm 0.042$ \\
\hline $\mathrm{H} / \mathrm{C}$ & $1.3 \pm 0.03$ & $1.6 \pm 0.04$ \\
\hline
\end{tabular}

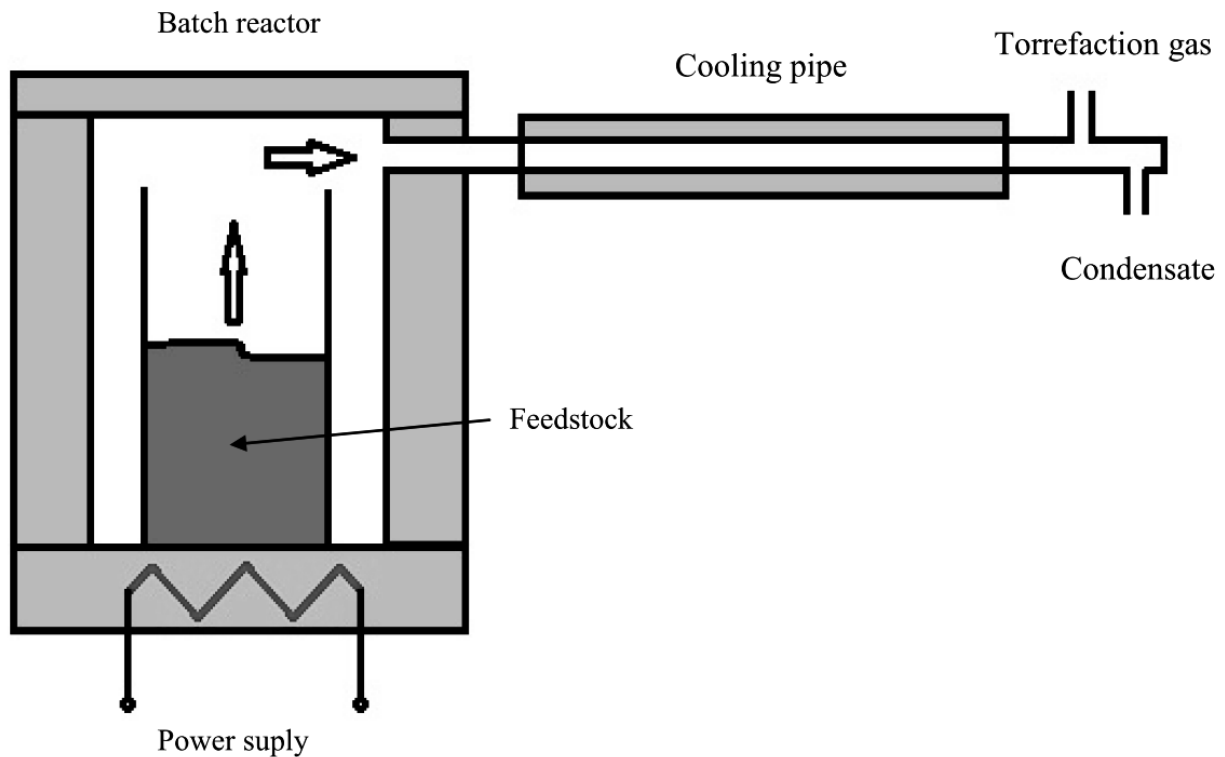

Fig. 1. Design of torrefaction batch reactor 
ambient temperature and took 10 to 20 minutes depending on target temperature. The target temperature was maintained for one hour and then the samples were left in the furnace until cooling down. Cooled samples where weighed with $0.1 \mathrm{mg}$ accuracy to determinate the mass loses.

\section{Analytical methods}

The range of analyzed parameters of the SS, sawdust and biochars was chosen according to the literature and they were as follows: moisture (Fisher et al. 2012), lower heating value - LHV (Ratte et al. 2011), higher heating value - HHV (Prins 2005), ash and volatile compounds content (Wannapeera and Worasuwannarak 2012), C, H, S content (Park et al. 2012).

Biomass/waste and biochar moisture were measured by the gravimetric method at $105 \pm 2^{\circ} \mathrm{C}$ using BINDER drying ovens with forced convection according to the Polish Standard [22]. Dried biomass/waste and biochar were grinded in MF10 IKA Werke laboratory mill to grain diameter below $0.25 \mathrm{~mm}$ according to the Polish Standard (PN-EN 14780:2011).

Analytical moisture, ash content and volatile compounds content where measured using thermogravimetric analysis on TGA ELTRA THERMOSTEP according to the Polish Standards (PN-EN 14780:2011, PN-EN 14774-1:2010E). $\mathrm{HHV}$ was measured in IKA Werke GmbH C2000 calorimeter. Carbon, sulfur and hydrogen content were measured with ELTRA CHS500 analyzer according to the Polish standards [PN-C-04301:1987P, PN-EN 15148:2010), . Analyses for each sample were conducted in three repetitions.

Based on those results, the following parameters were calculated:

Mass yield (Keipi et al. 2014)

$$
M y[d a f]=\left(\frac{M t}{M o}\right) * 100[\%]
$$

Mo - mass before process [daf] [g];

$\mathrm{Mt}$ - mass after process [daf] [g];

Energy yield: [2]

$$
E y=M y[d a f] * \frac{H H V t[d a f]}{H H V o[d a f]}[\%]
$$

$\mathrm{HHVt}$ - energy after process [MJ/kg d.b.]

$\mathrm{HHVo}$ - energy before process [MJ/kg d.b.]

H/C ratio (PN-G-04584:2001P)

$$
H / C=\frac{H / 1}{C / 12}
$$

$\mathrm{H}$ - percentage hydrogen content;

$\mathrm{C}$ - percentage carbon content;

1 - hydrogen molecular weight;

12 - carbon molecular weight.

\section{Statistical methods}

The results were statistically verified. The normality of the residuals' distribution was confirmed by Shapiro-Wilk's test, whereas the homogeneity of variances across the groups was verified based on Levene's test. The coefficient of variation was determined to verify the degree of variation:

$$
C v=\frac{\sigma}{\mu} C v=\frac{\sigma}{\mu}
$$

$\sigma-$ standard deviation

$\mu-$ mean

Differences between mean values of measured parameters were assessed using ANOVA at the significance level of $\mathrm{p}<0.05$. Post-hoc (a postieriori) Tukey's test was used to determine differences between the means of specific variants. Linear regressions, at significance level of $p<0.05$, between torrefaction temperature and biochar parameters were estimated.

\section{Results}

Moisture of untreated biomass/waste was $55.9 \%$ and $82.6 \%$ for sawdust and sewage sludge respectively. The residual water content in biochar differed depending on material source. At 200 and $220^{\circ} \mathrm{C}$, the moisture amount for sawdust dropped to $1.5 \%$, but when the temperature increased this value increased to $6 \%$ at $260^{\circ} \mathrm{C}$. Further increase of temperature decreased moisture to $4 \%$ at $300^{\circ} \mathrm{C}$ (Fig. 2). The mean $3 \%$ moisture of sewage sludge after torrefaction at $200^{\circ} \mathrm{C}$ varied significantly (high standard deviation value), but at $220^{\circ} \mathrm{C}$ it settled at $1 \%$. Increasing the temperature to $240^{\circ} \mathrm{C}$ resulted in $2 \%$ moisture, but the process temperature increase caused a slight decrease in water content (Fig. 2).

The distinct negative correlations between mass yield (dry ash free (d.a.f.) and standard) and process temperature for both materials have been found. The difference in solids' residue between the limiting experimental torrefaction temperature values for sawdust was two-fold higher than for sewage sludge (Fig. 3).

Biochar HHV changes due to rising temperatures differed between the treated material types. In the case of saw dust a strong positive correlation was observed. HHV of about $19 \mathrm{MJ} / \mathrm{kg}$ d.b. for $200^{\circ} \mathrm{C}$ was similar to that of untreated sawdust (Tab. 1) but further increase of the temperature caused significant $(\mathrm{p}<0.05)$ increase of HHV, up to $25.3 \mathrm{MJ} / \mathrm{kg}$ d.b. at $300^{\circ} \mathrm{C}$. The SS biochar HHV did not differ much from those of raw SS (Tab. 1) and all the temperature variants were within the range from 14.9 to $15.5 \mathrm{MJ} / \mathrm{kg}$ d.b. (Fig. 4). HHV d.a.f. values are slightly higher for sawdust biochar. A similar trend can be seen between that parameter and temperature. The SS $\mathrm{HHV}$ d.a.f. values ranged from $22.5 \mathrm{MJ} / \mathrm{kg}$ d.b. at $200^{\circ} \mathrm{C}$ to $27.4 \mathrm{MJ} / \mathrm{kg}$ d.b. at $300^{\circ} \mathrm{C}$. No correlation was confirmed.

In the case of both materials tested a significant energy loss was correlated to process temperature (Fig. 5). For sawdust, energy yield dropped from $93 \%$ at $200^{\circ} \mathrm{C}$ to $44 \%$ at $300^{\circ} \mathrm{C}$, but in the case of the SS that difference was smaller by about $25 \%$. Energy yield d.a.f. for sawdust was very similar. In the case of the SS, the values decreased substantially and ranged from $39 \%$ at $200^{\circ} \mathrm{C}$ to $30 \%$ at $300^{\circ} \mathrm{C}$.

Strong negative correlations between temperature and volatile compounds content were observed. The significant $(\mathrm{p}<0.05)$ drop of volatile compounds content in sawdust biochar from $77 \%$ d.b. to about $40 \%$ d.b. obtained in extreme temperatures was much higher than in the case of the SS (Fig. 6). 


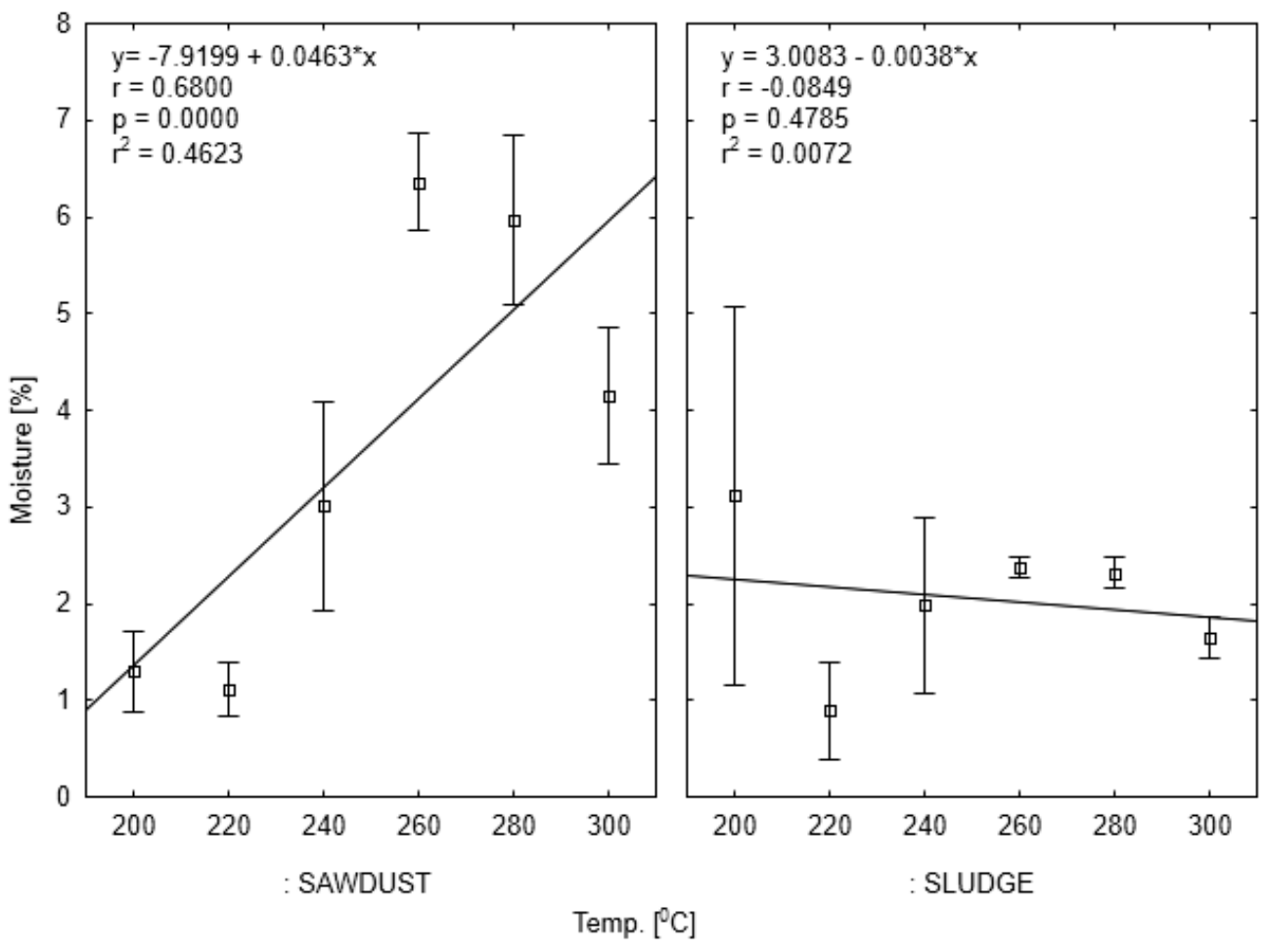

Fig. 2. Correlation between moisture biocarbons [\%] and process temperature
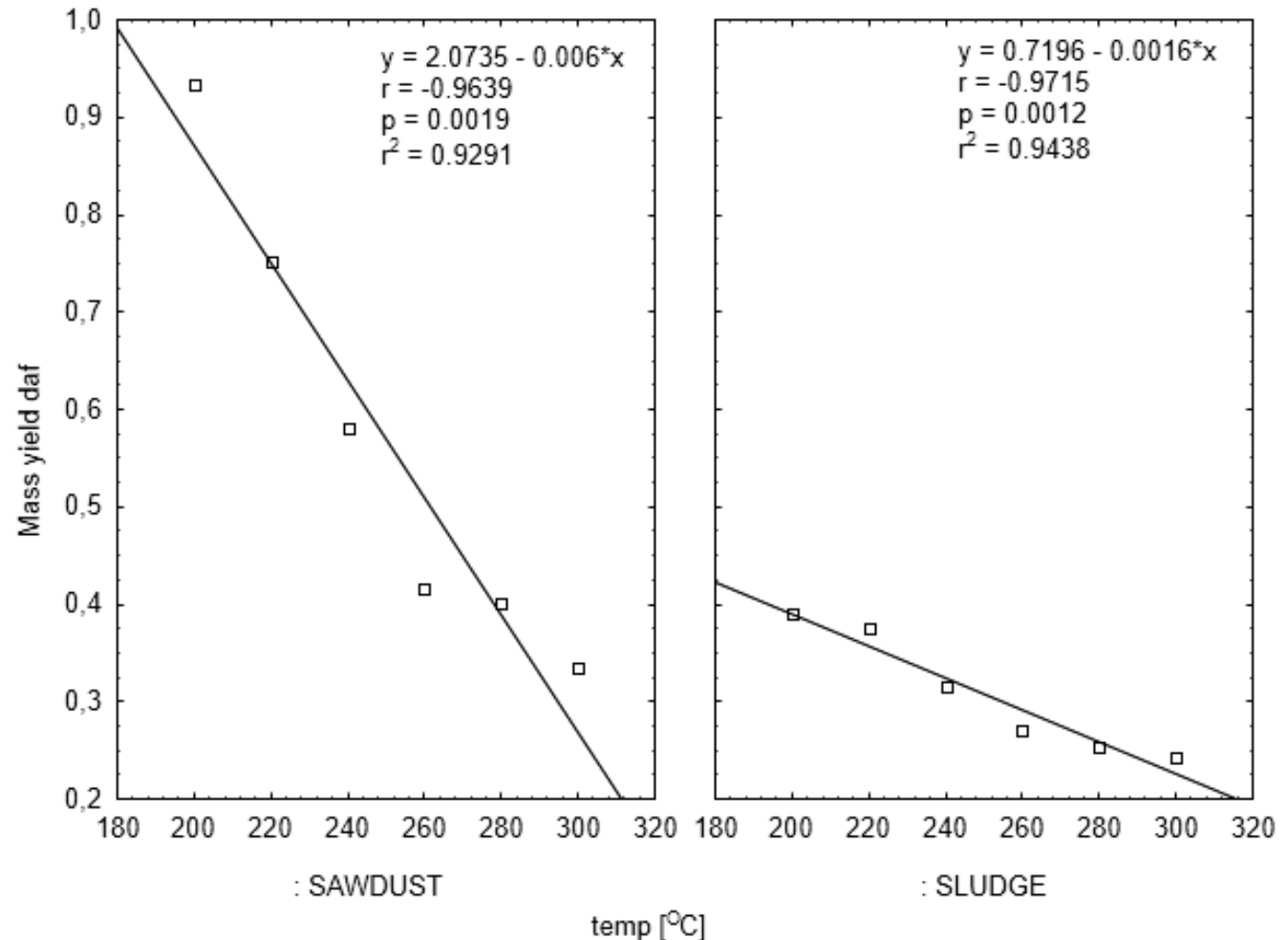

Fig. 3. Correlation between solids residue in biocarbons [\%] and process temperature

A statistically significant correlation between ash content and process temperature was observed for both materials (Fig. 7), but the content of ash in sawdust biochar ranged from 0.65 to $1.7 \%$ d.b. In the contrary, ash content in the SS biochar ranged among the values about 30 to 40 fold higher, reaching the highest ash content of $45.7 \%$ d.b. for $300^{\circ} \mathrm{C}$.
A slight sulfur content increase was observed for both materials with the process temperature increase, but $\mathrm{S}$ content in the SS biochar was over 100 fold higher than in sawdust biochar, ranging from 1.5 to $1.7 \%$ d.b. (Fig. 8).

The decrease of $\mathrm{H} / \mathrm{C}$ ratio was correlated negatively with temperature for both biomass/waste types (Fig. 9). These 


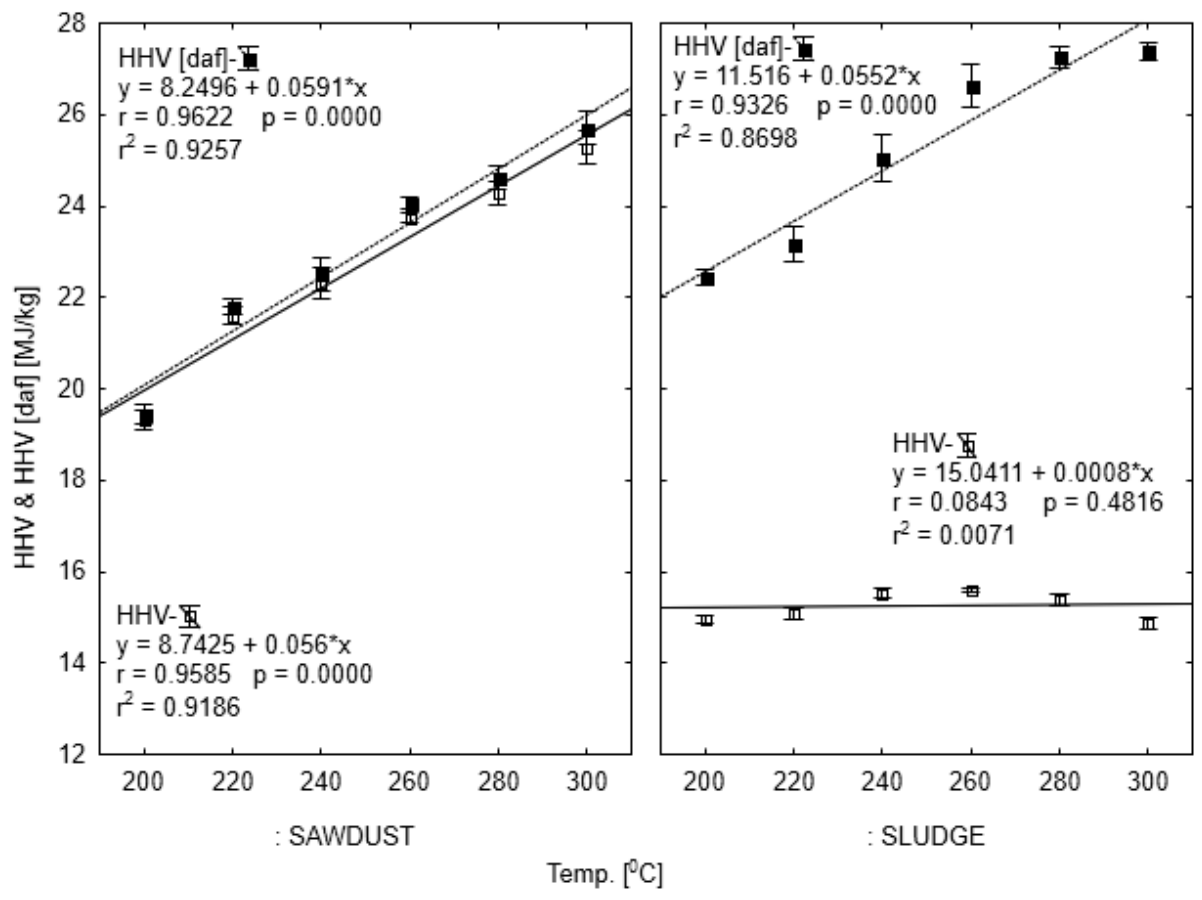

Fig. 4. Correlation between HHV and HHV [daf] [MJ/kg d.b.] of biocarbons and process temperature
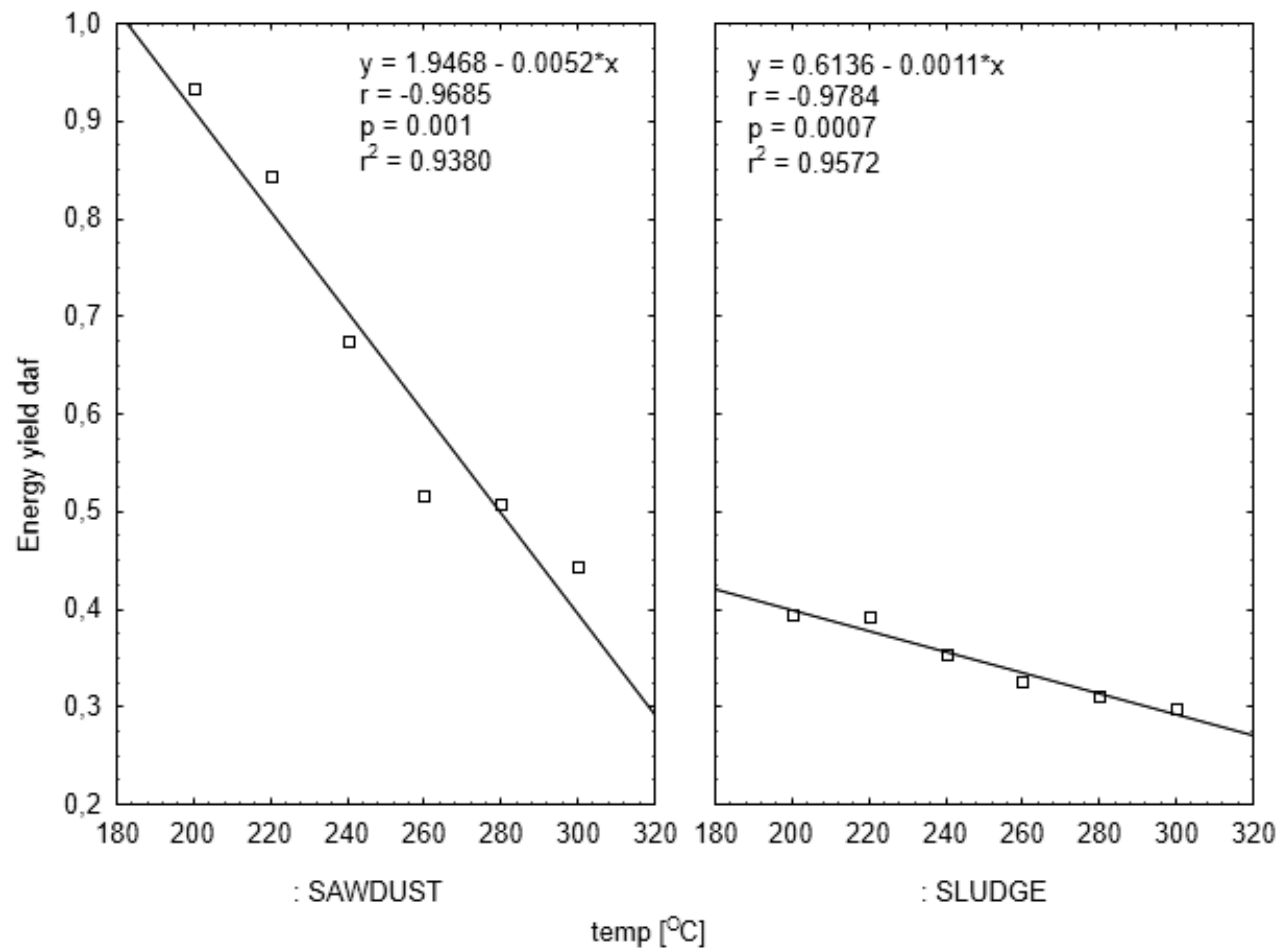

Fig. 5. Correlation between energy residue [\%] in biocarbons and process temperature

values dropped from 1.3 to 0.5 for sawdust biochar and from 1.5 to 1 for the SS biochar.

\section{Discussion}

Moisture is a very important parameter when processing the specific biomass type for energy production is considered. Lowering moisture increases LHV, prevents biological conversions of organic matter and decreases density. Inhibition of biomass biological decomposition is particularly essential when the biomass storage is considered. In the present study, sawdust moisture ranged from $1.1 \%$ to $6.6 \%$. The observed moisture increase together with temperature increase may be explained by high condensate content in the reactor during cooling phase. Also, the initial moisture of wood has an effect on torrefaction performance. Kim et al. (2012) torrefied biomass with initial moisture content of around $7 \%$. The authors obtained biochar with low water content of between 0.4 and 


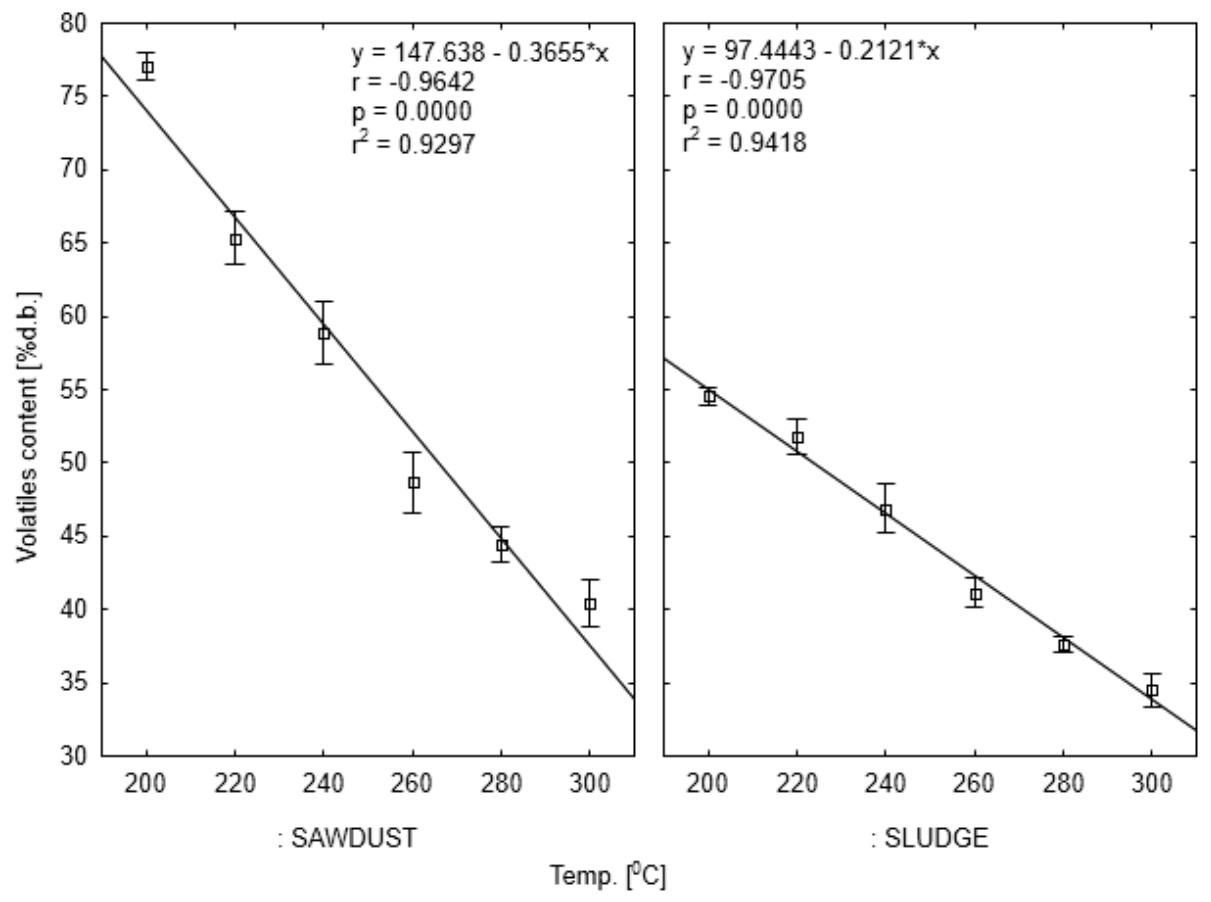

Fig. 6. Correlation between volatiles content [\% d.b.] in biocarbons and process temperature

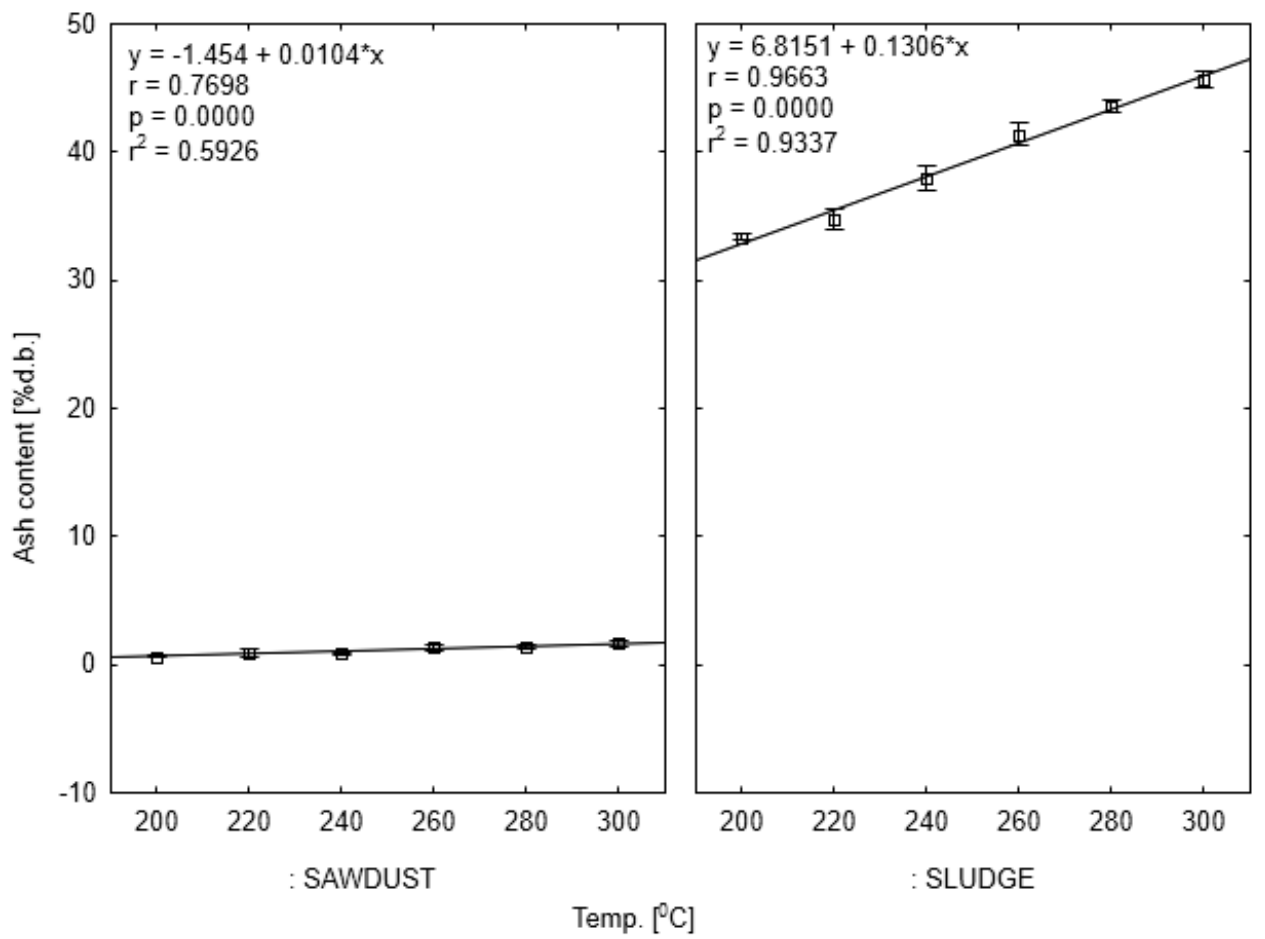

Fig. 7. Correlation between ash content [\% d.b.] in biocarbons and process temperature

$1.0 \%$. Bergman (2005) used raw sawdust with 35\% moisture and received $3 \%$ moisture of the torrefaction product. In our study, the initial sawdust moisture was about $56 \%$, therefore higher water content in biochar was found. This phenomenon may be related to wood cell walls and capillaries structure. When green wood dries, free water evaporates first while the cell walls are saturated with bound water. During torrefaction, not all the cell walls and capillaries are destroyed. Therefore, the final water content may be higher than in biochar from non-lignocellulosic biomass, like sewage sludge. The cells of microorganisms without cell walls (prokaryotes) are main component of SS waste. Therefore, thermal treatment causes destruction of all SS flocks' structures. It was confirmed by very high water removal efficiency from above $80 \%$ water content to about $1.5 \%$ in the present study as well as in (Dhungana 2012) who determined final $0.2 \%$ moisture of the SS biochar .

Moreover, the dry mass of both materials decreased significantly while the temperature increased. Sawdust dry 


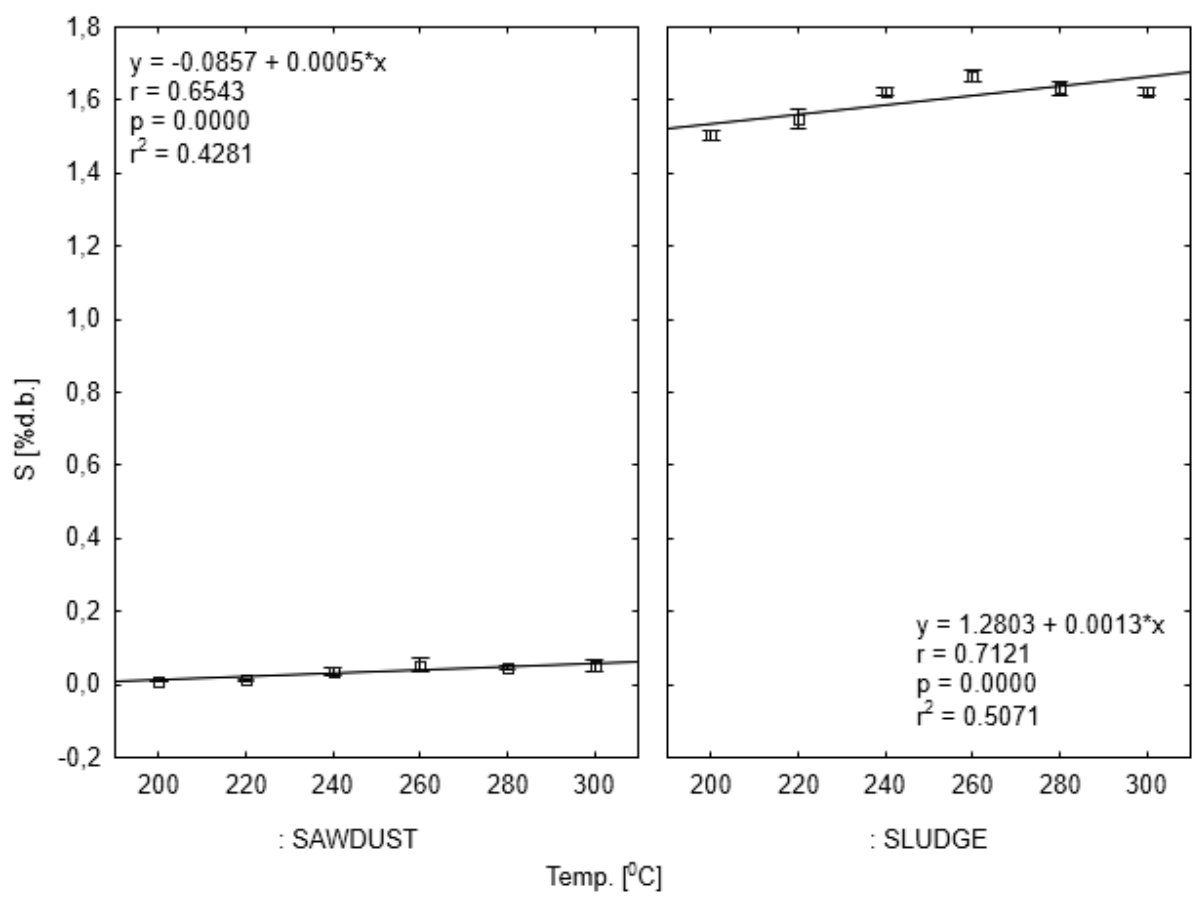

Fig. 8. Correlation between sulfur content [\% d.b.] in biocarbons and process temperature
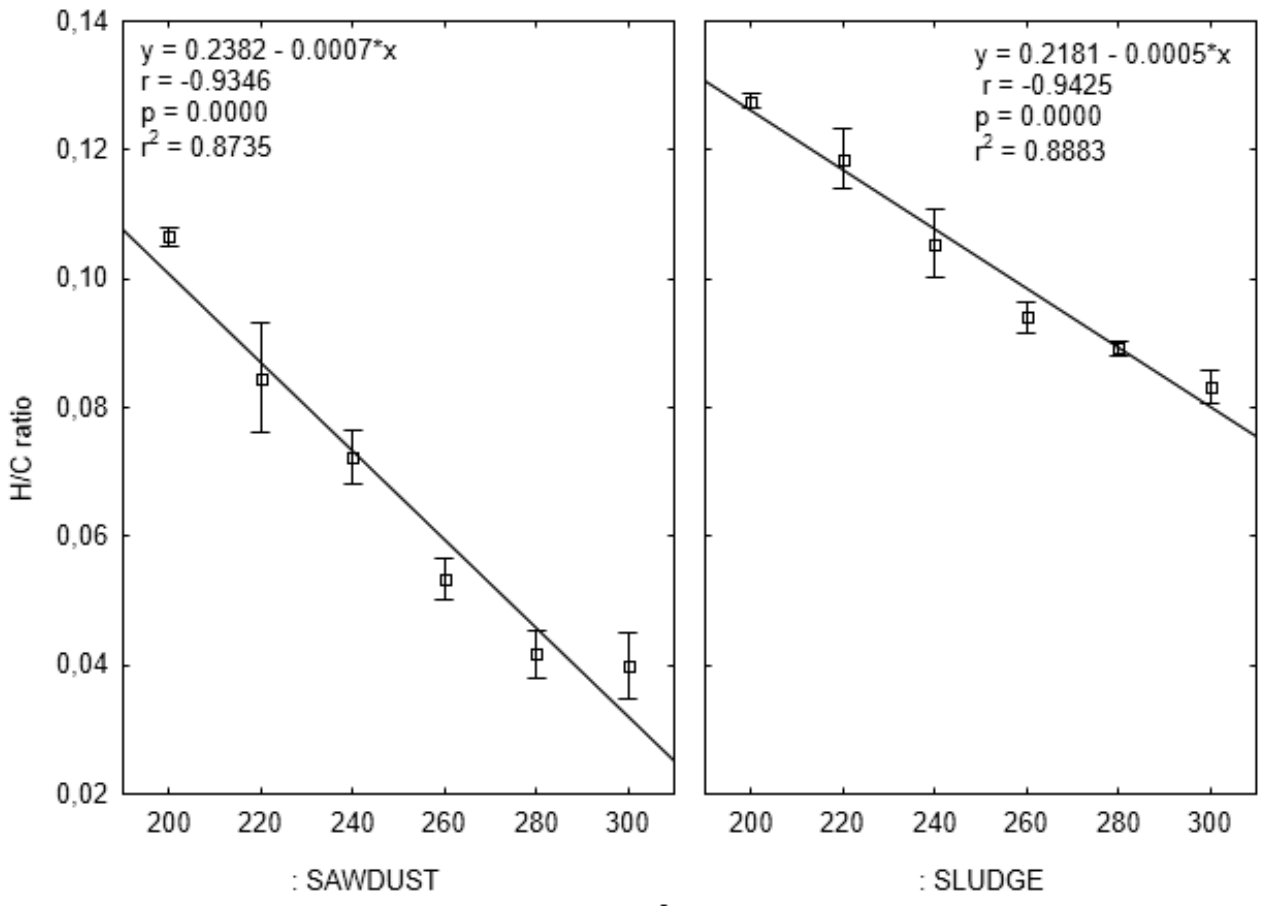

Fig. 9. Correlation between $\mathrm{H} / \mathrm{C}$ ratio of biocarbons and process temperature

mass residue dropped significantly $(\mathrm{p}<0.05)$ and correlated with temperature increase. A similar trend may be seen in (Wannapeera et al. 2011). The influence of microwave heating as opposed to standard torrefaction reactors where convective heating is applied and heat transfer is limited by thermal resistivity of the material, is another possible explanation. When microwave furnace is used, heat transfer limitations do not occur (Bergman and Kiel 2005). Sewage sludge dry mass yield decreased to $75 \%$ at 280 and $300^{\circ} \mathrm{C}$. A distinct correlation between temperature and mass loss was found. (Dhungana 2012) obtained similar results, but with a smaller slope of the regression curve, where increasing the temperature causes higher mass loss. The SS mass d.a.f. yield was significantly lower than that obtained by (Atienza-Martínez et al. 2013), but it was probably caused by a huge difference in the initial moisture. As in the case of sawdust, the differences between the experiments mentioned could be caused by different heating device types. 
Organic volatile compounds loss from biomass, which is strongly related to temperature increase, is another effect of torrefaction process (Wannapeera et al. 2011). This phenomenon was confirmed by the present study, but the determined results of organic volatile compounds content were lower than those presented by (Park et al. 2012) [19] who obtained 67\% content at $300^{\circ} \mathrm{C}$ and $60.1 \%$ content reported by (Fischer et al. 2012). That was probably caused by longer residence time and small particle size of sawdust increasing contact surface for vaporization. Similar volatile compounds content decrease was observed for sludge, which was also confirmed by (Dhungana 2012). However, sludge organic matter loss was much lower than that determined by (Dhungana 2012). This could be related to significantly lower initial volatile compounds content at $54 \%$ as compared to $76 \%$ in the paper mentioned above. Losses of organic matter influenced the calorific values and $\mathrm{H} / \mathrm{C}$ ratios of biochars.

Higher heating value is a parameter indicating how much energy might be generated from material during combustion, including energy formed during the gases condensation. Sawdust higher heating value increased from 19.3 to 25.3 $\mathrm{MJ} / \mathrm{kg}$ d.b. In the (Rousset et al. 2012) paper, where the process was conducted under similar operating conditions, the results where 21 and $22.5 \mathrm{MJ} / \mathrm{kg} \mathrm{d.b}$. at 240 and $280^{\circ} \mathrm{C}$ respectively. No significant differences between raw SS HHV and SS biochar HHV were found. Values ranged from 14.7 to $15.6 \mathrm{MJ} / \mathrm{kg}$ d.b. The highest mean value was obtained at $260^{\circ} \mathrm{C}$, and further temperature increase decreased HHV. In the experiment by (Atienza-Martínez et al. 2012), the authors obtained values fluctuation ranging from 12.05 to $13.2 \mathrm{MJ} / \mathrm{kg}$ d.b., but the same trend of decreasing HHV with increasing temperature was visible when residence time was longer. This phenomenon may be caused by the loss of organic volatile compounds. The differences in obtained biochar HHV values between the two types of biomass examined could be caused by stronger release of hydrogen by sawdust (Fig. 9), higher content of organic volatile compounds in sawdust biochar (Fig. 6) and much higher content of ash in SS biochar. SS HHV d.a.f. values where similar and the same trend of decreasing HHV with increasing temperature was visible. Similar HHV d.a.f. results support the theory of strong ash content influence on decreasing HHV with increasing temperature.

Volatile compounds, water and carbon oxide losses (Bergman 2005) due to temperature increase, especially those with small molecular weight, with relatively high share of hydrogen and low share of carbon, decreased values of $\mathrm{H} / \mathrm{C}$ ratio in biochars. For sawdust biochar, the $\mathrm{H} / \mathrm{C}$ ratio dropped from 1.3 to 0.4 . These values are much lower than the results obtained by (Kim et. al. 2012) ranging from 1.6 to 1.25 (Wannapeera and Worasuwannarak 2011), ranging from 1.77 to 1.08 , and (Rousset et al. 2012) ranging from 1.22 to 1.04 or (Park et al. 2012), where the lowest $\mathrm{H} / \mathrm{C}$ ratio was 0.9 . This difference is caused by higher mass and volatile compounds loss in the present study. In the case of SS biochar, $\mathrm{H} / \mathrm{C}$ ratio values were about two fold higher than those for sawdust biochar, which allowed maintaining the HHV values constant, considering decrease of organic matter loss and ash increase with temperature.

Energy yield is the parameter correlated strongly with mass residue. Both parameters showed similar correlation with increasing temperature for sawdust and sludge. The decrease in sawdust energy residue is much lower than that reported by (Wang et al. 2013), up to $72.3 \%$, and (Kim et al. 2012) up to $80.4 \%$. It was probably caused by higher mass loss, which was correlated to volatile compounds loss. Comparing sludge energy yield to (Dhungana 2012) and (Atienza-Martínez et al. 2013) experiments, higher values where obtained, which may be caused by relatively low mass loss, especially organic volatile compounds loss and HHV flat line.

Ash is an important parameter of each fuel. Significant, positive correlation between ash content in biochar and process temperature was recorded for both materials. A similar trend and very low values for sawdust were observed by (Kim et al. 2012), 0.95 to $1.23 \%$, and (Wannapeera et al. 2011) 0.7 to $1.5 \%$, indicating that biochar from sawdust was a good quality fuel for gasification or incineration. Sludge had multiple fold higher ash content ranging from 33 to $45 \%$, which may be an issue when SS biochar is gasified or burned. The problem with large quantities of ash produced during thermal reuse of SS biochar may be an obstacle for the direction of biochar reuse. Further research on SS biocarbon ash melting temperature should be conducted to identify whether any problems other than quantitative might arise.

The pollutants (sulfur) content is another qualitative parameter of the fuel. Biochar obtained from sawdust represents very good quality fuel with low sulfur content. In (Fischer et al. 2012) sawdust sulfur content was $0.01 \%$. The same value was obtained at 200 and $220^{\circ} \mathrm{C}$. (Atienza-Martínez et al. 2013) observed decreasing sulfur content while increasing residence time and temperature. The pollution content in sewage sludge biochar was over 100 fold higher than that of sawdust. It may pose another obstacle to use such a solid fuel due to the possible negative influence on the environment caused by $\mathrm{SO}_{\mathrm{x}}$ emission. It is possible that during the environmental impact assessment procedure of a power plant supplied with SS biochar, the $\mathrm{SO}_{x}$ emission levels will be exceeded.

\section{Conclusions}

Two kinds of biomass/waste were torrefied at different temperatures. The influence of torrefaction temperature on organic matter decrease in both materials was confirmed. In the case of sawdust, the increase of temperature decreased the dry mass content, energy content and $\mathrm{H} / \mathrm{C}$ ratio of biochar, but increased the calorific value of the fuel. Ash and sulfur content were constant and at a very low level. The opposite situation was observed for sewage sludge. The temperature increased the ash and sulfur content, which may bring possible problems with ash management and $\mathrm{SO}_{\mathrm{x}}$ emission during thermal reuse of SS biochar. Additionally, torrefaction did not increase the calorific values of biochars obtained from sewage sludge. The research conducted confirmed, that biochar obtained from sawdust is a very good quality fuel. The results obtained for sewage sludge showed that generation of biochar is possible, but some properties such as high ash and sulfur content may exclude that product from reuse for energy generation purposes. Therefore, further investigation, including laboratory scale evaluation of kinetics and energy demand of sewage sludge torrefaction, should be conducted. The ash melting point temperature of biochar obtained from sewage sludge should be also examined. The identified problems showed that the biochar obtained from sewage sludge does not meet the end-of-waste criteria given in Waste Framework Directive 2008/98/EC, which causes that its incineration must still be classified as waste incineration. 


\section{Acknowledgements}

The research was conducted with the financial support of the National Center for Research and Development (NCRD) Strategic Program: "Advanced technologies for energy generation. Task 4: Elaboration of integrated technologies for the production of fuels and energy from biomass, agricultural waste and other waste materials".

\section{References}

Atienza-Martínez, M., Fonts, I., Ábrego, J., Ceamanos, J. \& Gea, G. (2013). Sewage sludge torrefaction in a fluidized bed reactor, Chemical Engineering Journal, 222,15, pp. 534-545.

Bergman, P.C.A. \& Kiel, J.H.A. (2005). Torrefaction for biomass upgrading, Published at 14th European Biomass Conference \& Exhibition, Paris, France, 17-21 October 2005.

Bergman, P.C.A. (2005).Combined torrefaction and pelletisation - the TOP process, ECN Report, ECN-C-05-073.

Bień, J. \& Nowak, D. (2014). biological composition of sewage sludge in the aspect of threats to the natural environment, Archives of Environmental Protection, 40, 4, pp. 79-86.

Bridgeman, T.G., Jones, J.M., Shield, I. \& Williams, P.T. (2008). Torrefaction of reed canary grass, wheat straw and willow to enhance solid fuel qualities and combustion properties, Fuel, 87, pp. 844-856.

Bridgeman, T.G., Jones, J.M., Williams, A. \& Waldron, D.J. (2010). An investigation of the grindability of two torrefied energy crops, Fuel, 89, pp. 3911-3918.

Ciolkosz, D. \& Wallace, R. (2011). A review of torrefaction for bioenergy feedstock production, Biofuels, Bioproducts and Biorefining, 5, pp. 317-329.

Dhungana, A. (2012). Torrefaction of biomass, submitted in partial fulfilment of the requirements for the degree of Master of Applied Science, Dalhousie University 2012.

Eseltine, D., Sankar Thanapal, S., Annamalai, K. \& Ranjan, D. (2013). Torrefaction of woody biomass (Juniper and Mesquite) using inert and non-inert gases, Fuel, 113, pp. 379-388.

Fisher, E.M., Dupont, C., Darvell, L.I., Commandré, J-M., Saddawi, A., Jones, J.M., Grateaub, M., Nocquetb, T. \& Salvadore, S. (2012). Combustion and gasification characteristics of chars from raw and torrefied biomass, Bioresource Technology, 119, pp. 157-165.

Keipi, T., Tolvanen, H., Kokko, L. \& Raiko, R. (2014). The effect of torrefaction on the chlorine content and heating value of eight woody biomass samples, Biomass and Bioenergy, 66, pp. 232-239.

Kelessidis, A. \& Stasinakis, A.S. (2012). Comparative study of the methods used for treatment and final disposal of sewage sludge in European countries, Waste Management, 32, pp. 1186-1195.

Kim, Y.H., Lee, S.M., Lee. H.W. \& Lee, J.W. (2012). Physical and chemical characteristics of products from the torrefaction of yellow poplar (Liriodendron tulipifera), Bioresource Technology, 116, pp.120-125.

Lehmann, J., Rillig, M.C., Thies, J., Masiello, C.A., Hockaday, W.C. $\&$ Crowley, D. (2011). Biochar effects on soil biota - A review, Soil Biology and Biochemistry, 43, pp. 1812-1836.

Lipinsky, E.S., Arcate, J.R. \& Reed, T.B. (2002). Enhanced wood fuels via torrefaction, Fuel Chemistry Division Preprints, 4, pp. 408-410.

Mimmoa, T., Panzacchib, P., Baratieri, M., Davies, C.A. \& Tonon, G. (2014). Effect of pyrolysis temperature on miscanthus (Miscanthus $\times$ giganteus) biochar physical, chemical and functional properties, Biomass and Bioenergy, 62, pp. 149-157.

Montross, M. \& Crofcheck, C. (2010). Thermochemical Conversion of Biomass to Liquid Fuels and Chemical, RSC Publishing, 2010.
Park, S.W., Jang, C.H., Baek, K.R. \& Yang, J.K. (2012). Torrefaction and low-temperature carbonization of woody biomass: Evaluation of fuel characteristics of the products, Energy, 45, pp. 676-685.

Phanphanich, M. \& Mani, S. (2011). Impact of torrefaction on the grindability and fuel characteristics of forest biomass, Bioresource Technology, 102, pp.1246-1253.

Polish standard. (1987). PN-C-04301:1987P, Coke and semi-coke of coal. Determination of carbon and hydrogen content.

Polish standard. (2010). PN-EN 14774-1:2010E, Solid biofuels - Determination of moisture content - drier method - Part 1: Total moisture - Reference method.

Polish standard. (2010). PN-EN 14775:2010, Solid biofuels - Ash content determination.

Polish standard. (2011). PN-EN 14780:2011, Solid biofuels - Samples preparation.

Polish standard. (2010). PN-EN 15148:2010, Solid biofuels - Determination of volatile compounds content.

Polish standard. (2001). PN-G-04584:2001P, Solid fuels. Determination of total sulfur and fly ash with automatic analyzers.

Prins, M.J. (2005). Thermodynamic Analysis of Biomass Gasification and Torrefaction, Ph.D. thesis, Technische Universiteit Eindhoven 2005.

Ratte, J., Fardet, E., Mateos, D. \& Hery, J.S. (2011). Mathematical modelling of a continuous biomass torrefaction reactor: TORSPYD column, Biomass and Bioenergy, 35, pp. 3481-3495.

Rousset, P., Macedob, L., Commandréa, J.M. \& Moreirab, A. (2012). Biomass torrefaction under different oxygen concentrations and its effect on the composition of the solid by-product, Journal of Analytical and Applied Pyrolysis, 96.

Smith, S.R. (2008) The implications for human health and the environment of recycling biosolids on agricultural land, Imperial College of London, London 2008.

Sohi, S., Lopez-Capel, E., Krull, E. \& Bol, R. (2009). Biochar, climate change and soil: a review to guide future research, CSIRO Land and Water Science Report 05/09.

Stasta, P., Borana, J., Bebara, L., Stehlika, P. \& Oral, J. (2006). Thermal processing of sewage sludge, Applied Thermal Engineering, 26, pp. 1420-1426.

van der Stelt, M.J.C., Gerhauser, H., Kiel, J.H.A. \& Ptasinski, K.J. (2011). Biomass upgrading by torrefaction for the production of biofuels: A review, Biomass and Bioenergy, 35, pp. 3748-3762.

Verhoeff, F., Arnuelos, A.A., Boersma, R., Pels, J.R., Lensselink, J., Kiel, J.H.A. \& Schukken, H. (2011). Torrefaction Technology for the production of solid bioenergy carriers from biomass and waste, $E C N-E-11-039$.

Wang, C., Peng, J., Li, H., Bib, X.T., Legros, R., Lim, C.J. \& Sokhansanj, S. (2013). Oxidative torrefaction of biomass residues and densification of torrefied sawdust to pellets, Bioresource Technology, 127.

Wannapeera, J., Fungtammasan, B. \& Worasuwannarak, N. (2011). Effects of temperature and holding time during torrefaction on the pyrolysis behaviors of woody biomass, Journal of Analytical and Applied Pyrolysis, 92, pp. 99-105.

Wannapeera, J. \& Worasuwannarak, N. (2012). Upgrading of woody biomass by torrefaction under pressure, Journal of Analytical and Applied Pyrolysis, 96, pp. 173-180.

Werle, S. (2012) Possibility of NOx emission reduction from combustion process using sewage sludge gasification gas as an additional fuel, Archives of Environmental Protection, 38, 3, pp 81-89.

Wiśniewski, D. \& Gołaszewski, J. (2013). Thermal treatment of dewatered digestate for energy use, International Anaerobic Digestion Symposium at Biogas World 2013, Berlin, 23-25 April, 2013. 